Amasya İlahiyat Dergisi - Amasya Theology Journal

ISSN 2667-7326 | e-ISSN 2667-6710

Haziran / June 2019, 12: 195-221

\title{
Câhiliye Dönemi Şairlerinden El-Efveh El-Evdî'de Fahr Teması
}

The Theme of Fakhr in the Works of Jahiliyyah Period Poet al-Afwah al-Awdi

\author{
Ahmet Şen \\ Dr. Öğr. Üyesi, Erzincan Binali Yıldırım Üniversitesi, İlahiyat Fakültesi, Arap \\ Dili ve Belağatı Anabilim Dalı \\ Assistant Professor, Erzincan Binali Yıldırım University, Faculty of Theology, \\ Department of Arabic Language and al-Balagha \\ ahsen5224@gmail.com \\ Erzincan/Türkey \\ orcid.org/0000-0003-4370-6962
}

\section{Erdoğan Demir}

Arş. Gör., Erzincan Üniversitesi, İlahiyat Fakültesi, Arap Dili ve Belağatı Anabilim Dalı

Research Asistant, Erzincan University, Faculty of Theology, Department of Arabic Language and al-Balagha edemir2131@gmail.com

Erzincan/TURKEY orcid.org/0000-0003-0391-9824

\section{Makale Bilgisi / Article Information}

Makale Türü / Article Types: Araştırma Makalesi / Research Article

Geliş Tarihi / Received: 29 Ocak / January 2019

Kabul Tarihi / Accepted: 16 Mayıs / May 2019

Yayın Tarihi / Published: 20 Haziran / June 2019

Yayın Sezonu / Pub Date Season: Haziran / June

Sayı / Issue: 12 Sayfa / Pages: 195-221 
196 | A. ŞEN \& E. DEMIR / Câhiliye Dönemi Şairlerinden el-Efveh el-Evdî'de Fahr Teması

Atıf / Cite as: Şen, Ahmet - Demir, Erdoğan. "Câhiliye Dönemi Şairlerinden ElEfveh El-Evdî'de Fahr Teması [The Theme of Fakhr in the Works of Jahiliyyah Period Poet al-Afwah al-Awdi]". Amasya Ilahiyat Dergisi-Amasya Theology Journal 12 (June 2019): 195-221.

https://doi.org/10.18498/amailad.579971.

Intihal / Plagiarism: Bu makale, en az iki hakem tarafından incelendi ve intihal içermediği teyit edildi. / This article has been reviewed by at least two referees and scanned via a plagiarism software.

Copyright (C Published by Amasya Üniversitesi, İlahiyat Fakültesi / Amasya University, Faculty of Theology, Amasya, 05100 Turkey. All rights reserved. https://dergipark.org.tr/amailad

\title{
The Theme of Fakhr in the Works of Jahiliyyah Period Poet al-Afwah al-Awdi
}

\begin{abstract}
al-Afwah, whose real name was Salâ'a b. 'Amr b. Mâlik b. 'Avf b. al Hâris b. 'Avf b. Munabbih b. Evd b. Sa'b b. Sa'd el-'Asîre was a member of the Madhhij tribe. He lived during the late Jahiliyyah Period. He was rumored to have died in 570 or 560. The word "fakhr" means that a person cares about his past; exalts, values and prefers somebody over others; and boasts with some characteristics. As a term, "fakhr" refers to the type of poem in which the poets boast with themselves, their tribes, ancestors, lineage, beliefs, religion, sect, disposition, their literary and political prowess, talents and virtues, and even with their personal items and wealth such as swords, armors, horses, or with their long life and life experience. The opinions are divided among Arabic literature scholars regarding the acceptance of "fakhr" as a standalone theme in poetry. Afwah's "fakhr" poetry was generally based on his and his tribe's achievements in warfare and his performance in the battlefield. In such poems, Afwah describes the warriors of his tribe with reference to their horse-riding skills, sword mastery, and courage. Outside of the battle, he refers to his and his tribe's moral qualities, how he gives credit where credit is due, yet how he claims his rights even when he had to oppose strong and highborn people, how Northern Arabs were in the wrong and as a result, they were taught how to battle and how to ride horses, and how the tribe of Ewd would never take a hostile action lightly.
\end{abstract}


A. ŞEN \& E. DEMIR / The Theme of Fakhr in the Works of Jahiliyyah Period Poet

al-Afwah al-Awdi | 197

\section{Summary}

Al-Afwah, whose real name was Salâ'e b. 'Amr b. Mâlik b. 'Avf b. al-Hâris b. 'Avf b. Munabbih b. Evd b. Sa'b b. Sa'd el-'Asîre was a member of the Madh'hij tribe. His kunya was Abu Rebî‘a. For Al-Afwah, there are also those who call al-Azdi. The poet was one of the well-known cavalrymen of the Arabs, which naturally reveals that he was a warrior. He spent most of his life in battles, in which he emerged victorious most of the time. Since he was a wise poet, the elegance of his words has survived till today. Scholars voiced many opinions regarding his poetry. Due to his choice of words and descriptions in his poems, Afwah's poems and poetry eclipsed others. Informed by his father, Ibn al-Kalbī (d. after 204/819) says, "Afwah was one of the leading and most prominent poets of the Jahiliyyah period. He was the chieftain of his tribe and commanded them in battle. His tribe loved him and followed his instructions. He was also considered one of the rulers of Arabs." Abû Hilāl al-'Askarî (d. after 400/1009) says, "Afwah was the first to liken the hooves of the horses to stones." Afwah was considered a major Arab poet. He lived during the late Jahiliyyah Period. He was rumored to have died in 570 or 560 . Based on both rumors, it can be said that he lived around half a century before the Hegira. The word "fakhr" means that a person cares about his past; exalts, values and prefers somebody over others; and boasts with some characteristics. As a term, "fakhr" refers to the type of poem in which the poets boast with themselves, their tribes, ancestors, lineage, beliefs, religion, sect, disposition, their literary and political prowess, talents and virtues, and even with their personal items and wealth such as swords, armors, horses and especially camels, or with their long life and life experience. The opinions are divided among Arabic literature scholars regarding the acceptance of "fakhr" as a standalone theme in poetry. While Abû Hilal al-Askarî is discussing theme of poetry, he considers the fakhr and the dirge in the praise. On the other hand, Ibn Sallâm alJumahî (d. after 231/846) considers it in the basic poetry subjects; likewise, Ibn Rashiq al-Qayrawani (d. after 456/1064) also sees it as one of the main subjects of honorary poetry. Although it is frowned upon for a civilized person to praise others and especially oneself, in the moral landscape of the Jahiliyyah Period, selfpraise of the poets was not opposed. Afwah's "fakhr" poetry was generally based on his and his tribe's achievements in warfare and his performance in the battlefield. In such poems, Afwah describes the warriors of his tribe with reference to their horse-riding skills, sword mastery, and courage. Outside of the battle, he refers to his and his tribe's moral qualities, how he gives credit where 
198 | A. ŞEN \& E. DEMIR / Câhiliye Dönemi Şairlerinden el-Efveh el-Evdî'de Fahr Teması

credit is due, yet how he claims his rights even when he had to oppose strong and highborn people, how Northern Arabs were in the wrong and as a result, they were taught how to battle and how to ride horses, and how the tribe of Ewd would never take a hostile action lightly. The poet describes that not everybody can join and keep up with them for they are very courageous, they fought other tribes and took their women captive yet no other tribe ever took their women captive, they are determined to take revenge on Benî 'Âmir tribe, which is their enemy, they prefer paying ransom to spilling blood, those who wish to learn how his tribe attacks the enemy, should ask this to their tribe or to their enemies, they left the leaders of hostile tribes begging for food, and they have left their wives in tears. Again, when describing their battles with the Northern Arabs, Afwah speaks of his and his tribe's benevolence, generosity, and their sacrifices to protect their neighbors and he remarks that he charged into the battlefield on his horse with no fear. A major subject of the Arabic poetry in the Jahiliyyah period, "fakhr" was featured prominently in Afwah's poems. As he praises himself and his tribe, Afwah highlights virtues such as courage, benevolence, charitableness, horseriding, and use of other weapons of war, and combat experience. Afwah reveals their outstanding achievements in their battles with Northern Arabs and the despair they have inflicted upon their enemies. In his poems, the poet also draws attention to the sites of their battles with their enemies.

Keywords: Arabic Language and Literature, Afwah, Fakhr, Jahiliyyah, Madhhij.

\section{Öz}

\section{Câhiliye Dönemi Şairlerinden El-Efveh El-Evdî'de Fahr Teması}

Asıl adı Salâ'e b. 'Amr b. Mâlik b. 'Avf b. el-Hâris b. 'Avf b. Munebbih b. Evd b. Sa'b b. Sa'd el-'Aşîre olan Efveh, Mezhic kabilesindendir. O yakın dönem Câhiliye devrinde yaşamıştır. Fahr kelimesi, sözlükte kişinin atalarını sayması, bir kimseyi başka birine kıyasla yüceltmesi, değerli görmesi, tercih etmesi, birtakım özelliklerle övünmek anlamlarına gelir. Terim olarak fahr, şairlerin kendilerinden, kabile, soy, nesep, inanç, din, mezhep ve meşreplerinden edebî ve siyasî güçleriyle şiirdeki ustalık, yetenek ve faziletlerinden, hatta kılıç, zırh, at ve özellikle deve gibi şahsi mal ve eşyalarından veya uzun ömürleriyle hayat tecrübelerinden övünerek söz ettikleri şiir türünü ifade eder. Fahrın müstakil bir şiir teması olarak kabul edilmesiyle ilgili Arap Edebiyatçıları arasında görüş farklılıkları vardır. Efveh, fahr şiirlerini genel olarak savaşlarda kendisinin ve kavminin kazandığı başarılar ve savaş meydanlarında sergilediği performans üzerine bina etmiştir. Bu tür şiirlerinde Efveh, kavminin savaşçılarının ata binme 
A. ŞEN \& E. DEMIR / The Theme of Fakhr in the Works of Jahiliyyah Period Poet al-Afwah al-Awdi I 199 yeteneği, kılıç kullanma becerisi ve cesaretlerine dair betimlemelerde bulunmuş, savaş dışında yine kendisinin ve kavminin sahip olduğu bazı ahlâkî nitelikleri, hak sahibine hakkını verdiğini fakat haklı olduğu durumda da muhatabı güçlü ve soylu da olsa hakkını alma kararlığını, Kuzey Araplarının yanlış yaptığını ve bunun sonucunda kendilerine nasıl savaşılacağının, ata nasıl binileceğinin öğretildiğini ve düşmanca saldırı karşısında Evd kabilesinin asla yumuşak bir tavır takınmayacağını, zikreder.

Anahtar Kelimeler: Arap Dili ve Edebiyatı, Efveh, Fahr, Cahiliyye, Mezhic.

\section{Giriş}

Câhiliye dönemini işleyen kaynaklar, Kur'an'ın indiği ortamda Arapların yaşamına dair malumat sunmaları hasebiyle İslâmî ilimlerin tüm sahaları için ayrı bir önem taşımaktadır. Söz konusu dönemle ilgili elde edilecek bilgi için başvurulacak temel kaynaklardan biri de Cahiliye dönemi şairlerinin manzumeleridir. Bu dönemde yaşamış şairlerden biri de el-Efveh el-Evdî'dir. Makalemizde Efveh'in hayatı ve fahr temalı şiirlerine değindik.

\section{1. el-Efveh el-Evdi'nin Hayatı ve Şairliği}

Asıl adı Salâ'e b. 'Amr' b. Mâlik b. 'Avf b. el-Hâris b. 'Avf b. Munebbih b. Evd b. Sa'b b. Sa'd el-'Aşîre olan Efveh, Mezhic kabilesindendir. Künyesi, Ebû Rebî‘a'dır. İsminin kelime anlamı güzel koku çıkarmak için bitkilerin üzerinde dövüldüğü geniş taş, bir çeşit havan demektir. el-Efveh el-Evdî için ayrıca el-Ezdî diyenler de vardır. ${ }^{3}$ Bunun sebebi Ezdîler ile övünmesi ve onları öven şiirler söylemesidir. ${ }^{4}$

1 Ebû Muhammed Abdullāh b. Müslim b. Kuteybe ed-Dîneverî, eş-Şi'r ve'ş-Şu'arâ' (Kahire: Dâru'l-Hadîs, 2003), 1: 217; 'Ali b. Süleyman el-Ahfeş, el-İhtiyâreyn, nşr. Fahreddin Kabâve (Beyrut: y.y., 1999), 74.

2 Ebû Muhammed Ali b. Ahmed İbn Hazm, Cemheretu Ensâbi'l-'Arab (Beyrut: Dâru'lKutubi'l-'ilmiyye, 1983), 411.

3 Hasen b. Ahmed el-Hemedânî, Sıfatu Cezîreti'l-'Arab, nşr. Muhammed b. 'Ali el-Ekva' el-Hûlî (San'â': Mektebetu'l-İrşâd, 1990), 176.

4 Yâkût b. 'Abdillâh el-Hamevî, "Dâratu'n-Nassâb", Mu'cemu'l-Buldân (Beyrut: Dâru Sâdır, 1995), 2: 430. 


\section{0 | A. ŞEN \& E. DEMIR / Câhiliye Dönemi Şairlerinden el-Efveh el-Evdî'de Fahr Teması}

Şair Salâ'e'nin lakabı, el-Efveh'tir. Efveh أَفْوَ büyük dudaklı ve dişlek manasına gelir. Dudaklarının büyük ve ön dişlerinin bu şekilde belirgin olmasından dolayı Salâ'e'ye Efveh lakabı takılmıştır. ${ }^{5}$

Şairin Arapların meşhur süvarilerinden biri olması, doğal olarak onun savaşçı biri olduğunu göstermektedir. Ömrünün büyük bir bölümü, genellikle zaferi ile sonuçlanan savaşlar ile geçmiştir. Onun şairliği hakkında âlimlerden çok sayıda görüş nakledilmiştir. Şiirlerinde kullandığı kelime ve tasvirlerden dolayı Efveh'in şiirleri ve şairliği diğerlerinin önüne geçirilmiştir. Kelbî (ö. 204/819) babasından rivayet ederek şöyle der: Efveh, Câhiliye şairlerinin öncülerinden ve büyüklerindendi. Kavminin efendisi ve savaşlarda kumandanlarıydı. Kavmi onu sever ve görüşlerine göre hareket ederdi. Ayrıca Arapların hakîmlerinden sayılır. ${ }^{6}$ Ebû Hilâl el-'Askerî (ö. 400/1009'dan sonra) ise "Hâfiri (atın toynağı) taşlara benzeten ilk kişi Efveh'tir"7 demiştir. Ebu'lFerec el-İsfahânî ise Efveh için "O Arapların Câhiliye dönemi şairlerinin en meşhurlarındandır. Şiirlerinde hikmet, binicilik ve coşku temalarını çok işlemiştir. Hikmetli şairlerden sayılmaktadır. Binicilik hakkında kendisi için söylenenler hikmetinden daha az değildir. Şiirlerinde kendi kahramanlığı ve kavminin girdiği savaşlarda kazandığı zaferleri çokça işlemiştir. Ek olarak Câhiliye döneminde az rastlanır dakik tasvirler çizmektedir. Kavminin içinde kendisine savaşlarda özellikle de Benî 'Âmir ile yaptıkları savaşlarda itaat edilen bir liderdir" demektedir. ${ }^{8}$

Şiirlerinde garip kelimelere yer vermiştir. Bundan dolayı da birçok sözlükte kelimelerin anlamlarını açılarken lugatçlar onun şiirlerine başvurmuşlardır. Bu noktada onun şiirlerine başvurmayan Arapça bir sözlüğün olmadığını söylemek mümkündür. Örnek olarak İbn Manzûr yaklaşık kırk farklı yerde Efveh'in şiirlerine başvurmuştur. ${ }^{9}$

5 Hayreddin ez-Ziriklî, el-A'lâm (Beyrut: Dâru'l-'İlm li'l-Melâyîn, 2002), 3: 206-207.

6 Ebü'l-Ferec Ali b. Hüseyin el-İsfahânî, el-Ağĝn $̂$ (Beyrut: Dâru İhyâ'i't-Turâsi'l-'Arabî, 1995), 12: 389.

7 Ebû Hilâl Hasen b. 'Abdullah el-Askerî, Dîvânu'l-Me'ânî (Beyrut: Dâru'l-Cîl, ts.), 2: 111.

8 İsfahânî, el-A ğânî̀, 12: 389.

9 Salâ'e b. 'Amr el-Efveh el-Evdî, Dîvân, nşr. Muhammed Altuncî (Beyrut: Dâru Sâdır, 1998), 29. Ayrica bk. Muhammed b. Mukerrem el-İfrikî el-Mısrî İbn Manzûr, "Hacebe”, Lisânu'l-'Arab (Beyrut: Dâru Sâdır, 1414/1993), 1: 300; İbn Manzûr, "Hacebe", 1: 580; İbn Manzûr, "Ka'abe”, 1: 684; İbn Manzûr, “Lihb”, 1: 745. 
A. ŞEN \& E. DEMIR / The Theme of Fakhr in the Works of Jahiliyyah Period Poet

al-Afwah al-Awdi | 201

Efveh kadim Arap şairlerinden kabul edilir. O yakın dönem ${ }^{10}$ Câhiliye döneminde yaşamıştır. Efveh'in ölüm tarihine dair klasik kaynaklarda bilgi verilmemiştir. Luvîs Şeyho (ö. 1927) onun 570 yılında vefat ettiğini söylemektedir. ${ }^{11}$ Buna karşın Ömer Ferruh ise vefat yılı olarak 560'1 tercih eder. ${ }^{12}$ Her iki rivayeti göz önüne alarak şairin hicretten yaklaşık yarım asır önce yaşamış olduğunu söyleyebiliriz.

\section{Fahrın Tarifi ve Câhiliye Döneminde Fahr}

Fahr kelimesi, sözlükte kişinin atalarını sayması, ${ }^{13}$ bir kimseyi başka birine kıyasla yüceltmesi, değerli görmesi, tercih etmesi, $^{14}$ birtakım özelliklerle övünmek ${ }^{15}$ anlamlarına gelir. Terim olarak fahr:

"Şairlerin kendilerinden, kabile, soy, nesep, inanç, din, mezhep ve meşreplerinden edebî ve siyasî güçleriyle şiirdeki ustalık, yetenek ve faziletlerinden, hatta kılıç, zırh, at ve özellikle deve gibi şahsî mal ve eşyalarından veya uzun ömürleriyle hayat tecrübelerinden övünerek söz ettikleri şiir türünü ifade eder". ${ }^{16}$

10 Hakkında yalnızca kazılar sonucu çıkarılan kitabeler, tabletler ve başka eserler vasıtasıyla bilgi sahibi olduğumuz, Miladi 5. yüzyıldan önceki ilk cahiliye çağını, Miladi 5. yüzyıldan İslâmiyet'in gelişine kadar geçen yaklaşık bir asırlık dönem de ikinci cahiliye çağını oluşturur. Bk. Kenan Demirayak, Arap Edebiyatı Tarihi-1 (Erzurum: Fenomen Yayıncilık, 2012), 9.

11 Rizkullah b. Yûsuf el-Yesû'î Luvîs Şeyho, Şu'arâ'u'n-Nasrâniyye (Beyrut: y.y., 1890), 1: 70 .

12 Ömer Ferrûh, Târîhu'l-Edebi'l-'Arabî (Beyrut: Dâru'l-'İlm li'l-Melâyîn, 1981), 1: 133.

13 Ebû Bekr Muhammed b. el-Hasen İbn Dureyd, "Fahara”, Cemheretu'l-Luga, nşr. Remzî Munîr Ba'lbekkî (Beyrut: Dâru'l-'Ilm li'l-Melâyîn, 1987), 1: 589; Muhammed b. Ahmed el-Ezherî, "Fahara”, Tehzîbu'l-Luga, nşr. Muhammed 'Avad (Beyrut: y.y., 2001), 7: 154; Ebû Nasr İsmâ'îl b. Hammâd el-Cevherî, "Fahara”, Sihâh, nşr. Ahmed "Abdulgafûr 'Attâr (Beyrut: Dâru'1-'İlm li'l-Melâyîn, 1987), 2: 779.

14 Ebû'l-Huseyn Ahmed b. Fâris, "Fahara”, Mu'cemu Mekâyîsi'l-Luga, nşr. 'Abdusselâm Muhammed Hârûn (Kahire: y.y., 1366/1946), 4: 480.

15 İbn Manzûr, "Fahara”, 5: 48.

16 Cebbûr 'Abdunnûr, el-Mu'cemu'l-Edebî (Beyrut: Dâru'l-'İlm li'l-Melâyîn, 1979), 189; İsmail Durmuş, "Fahr", Türkiye Diyanet Vakfi İslam Ansiklopedisi (Ankara: TDV Yayınları, 1995), 12: 79; Bichr Farès, “Müfâhare”, İslam Ansiklopedisi (İstanbul: y.y., 18401980), 8: 790-791. 


\section{2 | A. ŞEN \& E. DEMIR / Câhiliye Dönemi Şairlerinden el-Efveh el-Evdî'de Fahr Teması}

Fahrın müstakil bir şiir teması olarak kabul edilmesiyle ilgili Arap Edebiyatçıları arasında görüş farklılıkları vardır. Ebû Hilâl el-'Askerî şiir konularını ele alırken fahr ve mersiyeyi medih şiiri içinde mütalaa etmiştir. ${ }^{17}$ Öte yandan İbn Sellâm el-Cumahî (ö. 231/846), medih, nesîb, heca ile birlikte fahrı da temel şiir konularından kabul ederken; ${ }^{18}$ aynı şekilde İbn Reşîk el-Kayrevânî (ö. 456/1064) de fahrı şiirin ana konularından biri olarak görür. ${ }^{19}$

Genellikle kasidenin bir bölümü olarak medihten sonra gelen fahr bazen şiirin diğer bölümleri arasında beyitler hâlinde yer alır, bazen de müstakil olarak nazmedilir. Fahr mahiyet itibariyle medihten başka bir şey olmadığı için onda güzel olan her şey bunda da güzel, çirkin olan her şey bunda da çirkin sayılmıştır. Bu bakımdan överken de övünürken de yaratılıştan gelen ve kalıcı olan vasıf ve faziletlerin dile getirilmesi istenir. Telakkiye göre insanın diğer canlılara olan üstünlüğü akıl, iffet, adalet ve kahramanlık gibi dört ana meziyeti sebebiyledir. Dolayısıyla eski Arap toplumunda bu ana hasletler ve bunlara bağlı diğer fitrî vasiflarla övme olumlu karşılanır; bunların dışındakilerle yapılan övgü ise hoş görülmezdi. Ayrıca bu medihlerin kısa, öz ve gerçeğe uygun olması arzu edilmekle beraber bu konuda mübalağa da yadırganmamıştır. Her ne kadar medeni bir insanın başkasını ve özellikle kendini övmesi hoş karşılanmasa da Câhiliye toplumunun ahlâk anlayışında şairlerin övünmelerine karşı çıkılmamıştır. Ayrıca fahrı sadece medhin değil hicvin de bir unsuru olarak görmek gerekir. Zira övme veya övünmeye vesile olan cesaret ve cömertlik başta olmak üzere hilm, azim, sebat, vefa, iffet, doğruluk, sabır, adalet, bağışlama, sır saklama, tevazu, zekâ ve akıl gibi iyi hasletler hiciv sırasında yerilene karşı kullanılır. Hasmının veya rakibinin ayıplarını sayan, belli hasletlerin onda mevcut olmadığını bu

17 Ebû Hilâl el-'Askerî, es-Sinâ'ateyn, nşr. Muhammed Ebu'l-Fadl İbrâhîm - Ali Muhammed el-Becâvî (Beyrut: el-Mektebetu'l-‘Unsuriyye, 1999), 131, Ebû Hilâl el'Askerî, Dîvânu'l-Ma'ânî, 1: 91; Ahmed Matlûb, Mu'cemu Mustalahâti'n-Nahvi'l'Arabiyyi'l-Kadîm (Beyrut: Meketebetu Lubnân, 2001), 310.

18 Muhammed b. Sellâm el-Cumahî, Tabakâtu Fuhûli'ş-Şu'arâ', nşr. Mahmûd Muhammed Şâkir (Cidde: Dâru'l-Medenî, ts.), 2: 279.

19 İbn Reşîk el-Kayrevânî, el-'Umde, nşr. Muhammed Muhyiddîn 'Abdulhamîd (Beyrut: y.y., 1981), 2: 143. 
A. ŞEN \& E. DEMIR / The Theme of Fakhr in the Works of Jahiliyyah Period Poet al-Afwah al-Awdi | 203

vesile ile ima etmiş olan şairin esas gayesi, hiciv olsa bile burada övünme unsurları bulunduğundan sonuçta bu şiir de bir fahrdır. ${ }^{20}$ Savaşlarda kahramanlık, yiğitlik, cesaret ve atılganlık gibi unsurların işlendiği hamase türü de fahr temasıyla yakından ilişkilidir. Zira İslamî dönem Arap şiirinde iki türün iç içe geçtiği görülür. ${ }^{21}$

\section{3- el-Efveh el-Evdî́nin Fahr Temalı Şiirleri}

Efveh, fahr şiirlerini genel olarak savaşlarda kendisinin ve kavminin kazandığı başarılar ve sergilediği performans üzerine bina etmiştir. Bu tür şiirlerinde kavminin savaşçılarının ata binme yeteneği, kılıç kullanma becerisi ve cesaretlerine dair betimlemelerde bulunmuştur. Ayrıca savaş dışında yine kendisinin ve kavminin sahip olduğu bazı ahlâkî nitelikleri de fahr şiirlerinde kullandığı görülür: (Kâmil)

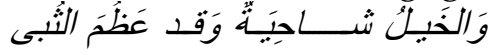

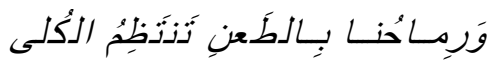

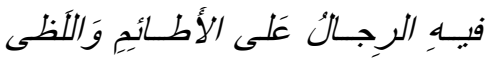

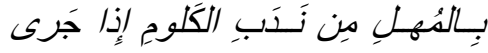

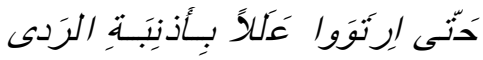

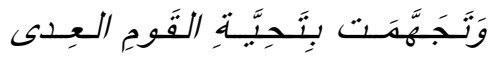

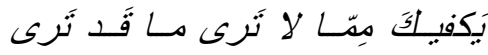

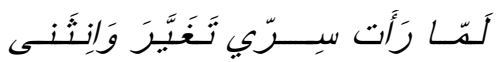

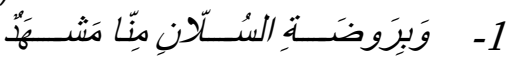

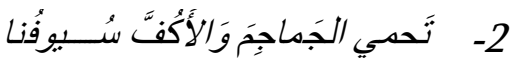

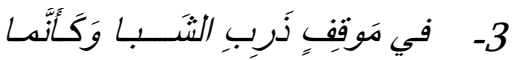

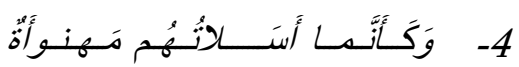

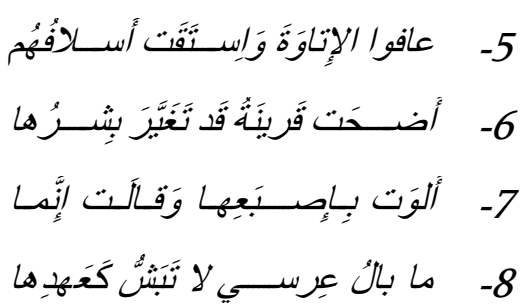

1- Sullân Dă̆ı'nın bahçelerinde (bıraktı̆̆ıııı bir) sahne (anı) vardır. Topluluklar izdiham oluşturduğunda, atlar heyecana gelir ve ă̆ızları açıktır.

2- Kılıçlarımız başlarımız ve ellerimizi korur. Mizraklarımız ise böbreklere saplanir.

20 Durmuş, “Fahr", 12: 79.

21 Hannâ el-Fâhûrî, el-Fahr ve'l-Hamâse (Kahire: Dâru'l-Ma'ârif, 1992), 38; İsmail Durmuş, "Hamase", Türkiye Diyanet Vakfı İslam Ansiklopedisi (Ankara: TDV Yayınları, 1997), 15: 437. 
204 | A. ŞEN \& E. DEMIR / Câhiliye Dönemi Şairlerinden el-Efveh el-Evdî'de Fahr Teması

3- Keskin kılıçların kızıştığı bir yerdeyiz. Adamlarımız kor ateşler içinde güçlü atlara binmişler gibi.

4- Yaralardan akan kanlarla mızraklarının ucu katranla yă̆lanmış gibi.

5- Kavmim haracı aldı. Onların ataları helâk kovasıyla ikinci defa ölüme kandl.

6- Karımın tavrı değişmeye başladı. Öldürülmek için gelen yabancılar selâmıla somurttu.

7- Parmă̆ıyla işaret etti ve dedi ki: "Gördüklerin görmediklerine yeter."

8- Ne oluyor karıma, hayret! Hiç bu kadar sevinmemişti Bünyem gevşeyip, zayıf düştüğ̈̈nden beri.

Hak ve hak sahibine dair iki beyitlik şiirinde hak sahibine hakkını verdiğini fakat haklı olduğu durumda da muhatabı güçlü ve soylu da olsa hakkını alma kararlı̆̆ını dile getirir:

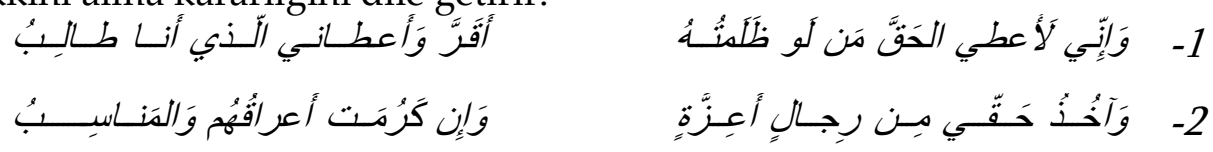

1- Şüphesiz ki ben, kendisine zulmettiğimi söyleyene hakkın veririm. O da istediğimi verir.

2- Güçlü adamlardan hakkımı alırım asil ve konum sahibi olsalar da.

Duhrudân mevkiinde yaptıkları savaşta atalarını asalet ve hırslarıyla öven Efveh, kavminin uysal atlarını ve keskin kılıçlarını da zikretmeyi unutmamıştır: (Vâfir)

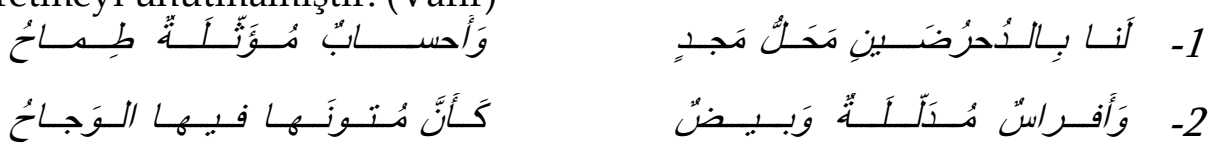

1- Duhrudân'da ${ }^{22}$ üstün bir konumumuz vardır saygıdeğer, asil ve hirslı atalarmiz.

2- Yumuşak başlı atlarımız ve parlak kılıçlarımız gövdesinde parlak taş varmış gibi.

Sabîb günü Benî Evd'in Benî 'Âmir'e saldırması ve çatışma sonunda büyük bir ganimet elde etmesi üzerine Efveh'in söylediği şiir fahr temasının işlendiği güzel bir örnektir:23 (Vâfir)

22 Yer ismidir. Bk. İbn Manzûr, “Duhrud”, 7: 149.

23 İsfahânî, el-A ğânî, 12: 390. 
A. ŞEN \& E. DEMIR / The Theme of Fakhr in the Works of Jahiliyyah Period Poet al-Afwah al-Awdi | 205
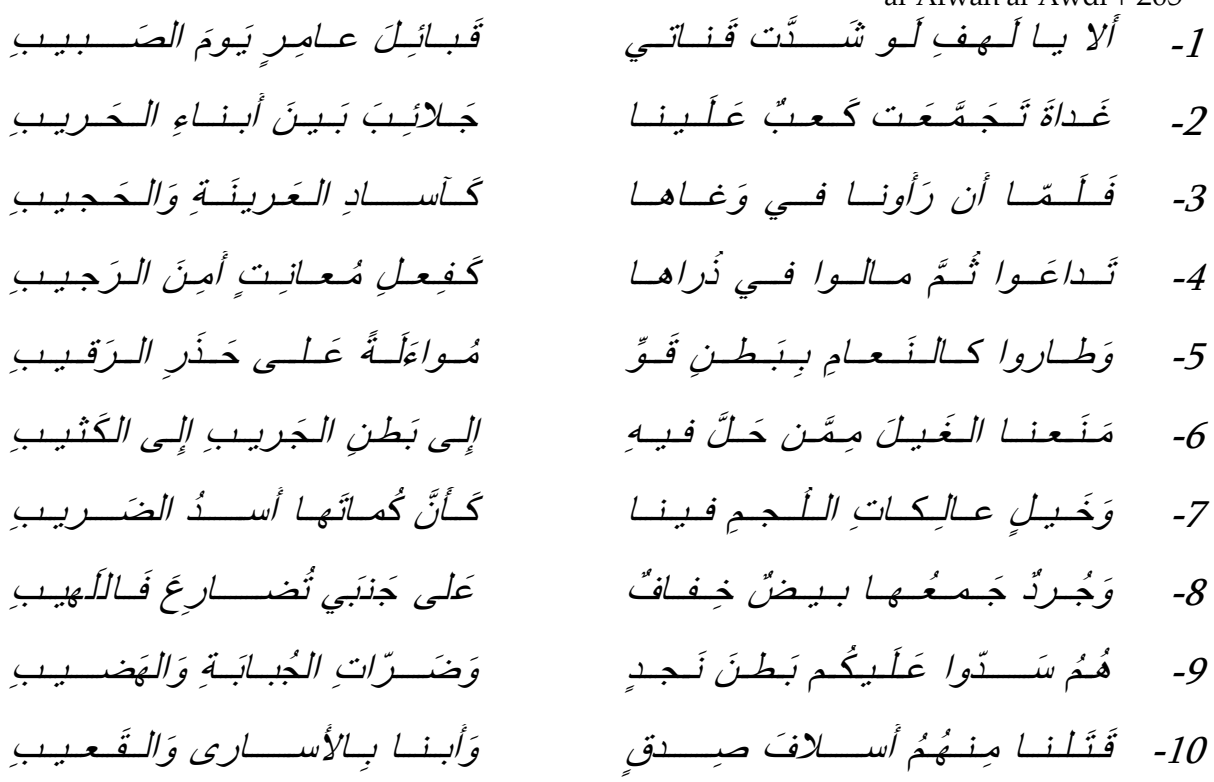

1- Ah keşke mizrağım 'Âmir kabilelerini kan dökülen o günde görseydi.

2- Savaşın çocukları olan bize karşı Kâ'b'ın kölelerini topladığı sabah,

3- Hacîb'te ${ }^{24}$ çalılıklardaki aslanlar gibi, kargaşada bizi gördükleri zaman,

4- Kaçışmak için bağrıştılar, sonra siperlere yöneldiler, ölümle karşılaşanın güçlü birinin emanına sı̆̆ınması gibi.

5- Batnu Kavvi'de ${ }^{25}$ devekuşu gibi uçtular. Takip edenlerin korkusundan kurtulmak için engelledi.

6- Vadideki sular kumluklara ve Cerîb' $e^{26}$ ulaşanları yakalamamızı

7- Atlarımız öfkeden gemlerini çĭ̆niyor. Silah kuşanmış süvarileri de saldırgan aslanlar gibiler.

24 Yer ismidir. Bk. Yâkût, "Hacîb”, 2: 226.

25 Basra ile Medine arasında bir vadidir. Bk. İsfahânî, el-Ăĝân̂, 22: 467.

26 Necid'te bir yer. Bk. İsfahânî, el-A ğân $̂$, 5: 28. 
206 | A. ŞEN \& E. DEMIR / Câhiliye Dönemi Şairlerinden el-Efveh el-Evdî'de Fahr Teması turluyor.

8- Asil savaşçılar taşıyan hızlı atlar Tüdari'27 ve Lehîb'in ${ }^{28}$ etrafını

9- Onlar, Necd'in vadilerini ve Cubâbe ${ }^{29}$ ile Hedîb'in ${ }^{30}$ tümseklerini kuşattılar.

10- İleri gelenlerini öldürdük ve çok sayıda esirle döndük.

Şair, kavminin Kuzey Araplarına karşı kazandı̆̆ı zafere dair söylediği şiirde, kendisi ve kavmiyle 10. beyitten itibaren övünmeye başlar. Efveh, Kuzey Araplarının yanlış yaptığını ve bunun sonucunda kendilerine nasıl savaşılacağının, ata nasıl binileceğinin öğretildiğini ve düşmanca saldırı karşısında Evd kabilesinin asla yumuşak bir tavır takınmayacă̆ını ifade eder: (Remel)
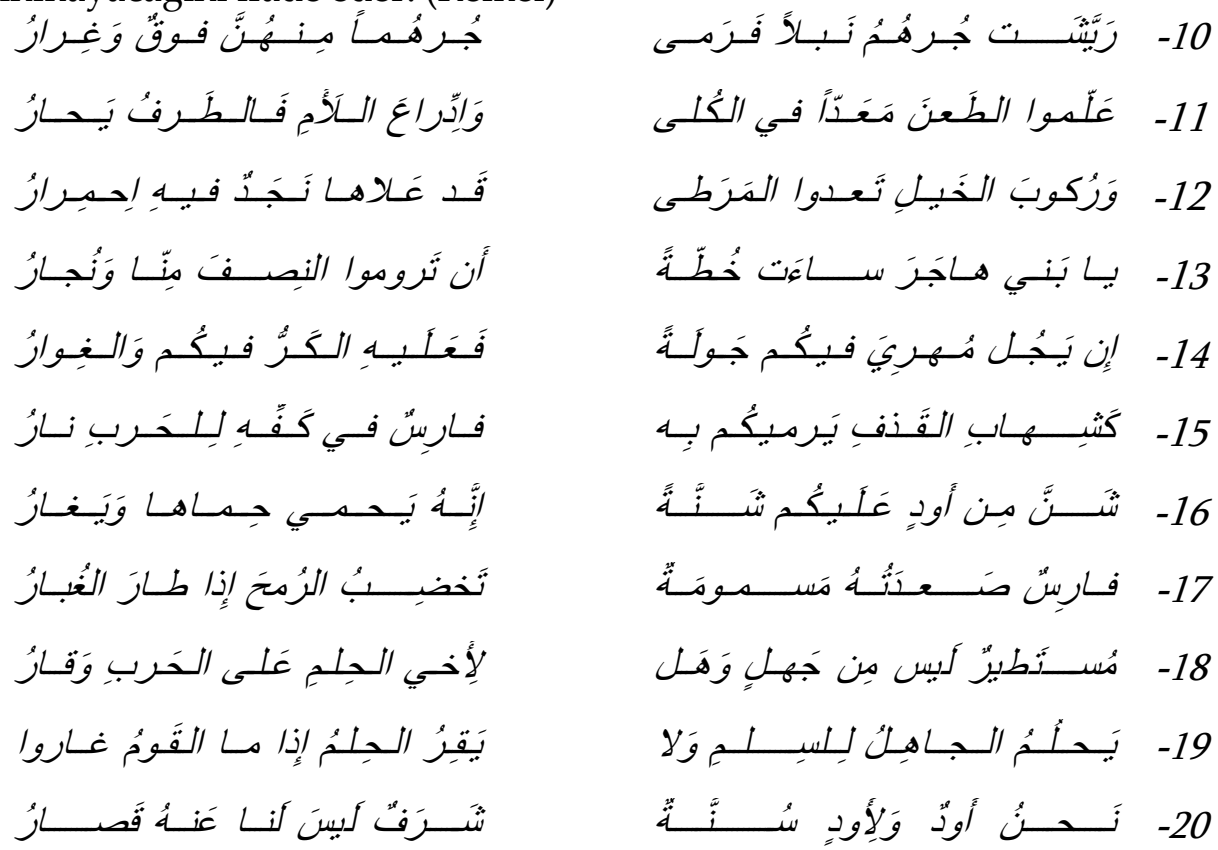

27 Bir yer veya dağdır. Bk. Ebu'l-Hasen 'Ali b. İsmâ‘̂̂l b. Sîde, el-Muhkem ve'l-Muhîtu'lA'zam, nşr. el-Hindâvî (Beyrut: Dâru'l-Kutubu'l-'ilmiyye, 2000), 1: 405.

28 Yer ismidir. İbn Manzûr, “Lihb”, 1: 745.

29 Yer ismidir. Bk. Ebû 'Ubeyd 'Abdullah b. 'Abdul'azîz el-Endelûsî, Mu'cemu Mestu'cime min Esmâi'l-Bilâd ve'l-Mevâdi' (Beyrut: 'Alemu'l-Kutub, 1983), 2: 361.

30 Yer ismidir. Ebû 'Ubeyd, Mu'cemu Mestu'cime min Esmâi'l-Bilâd ve'l-Mevâdi', 4: 1354. 
A. ŞEN \& E. DEMIR / The Theme of Fakhr in the Works of Jahiliyyah Period Poet

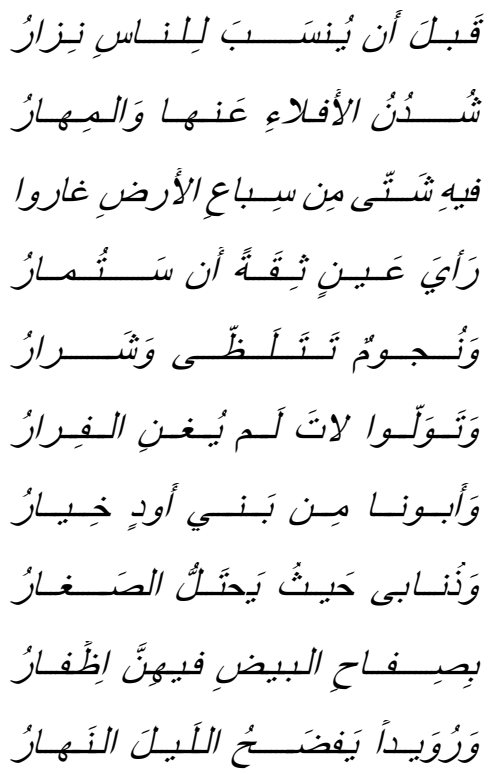
al-Afwah al-Awdi | 207
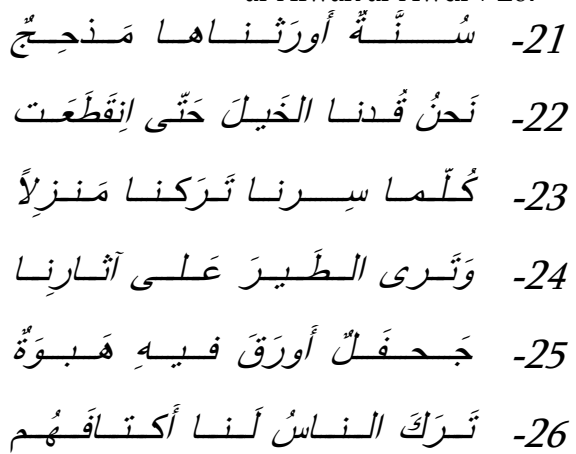

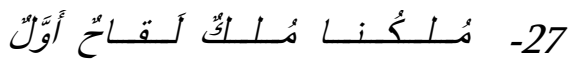
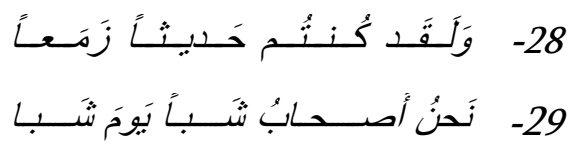

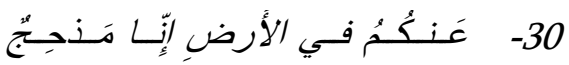

10- Cürhüm ${ }^{31}$ oklar hazırladı. Cürhüm itaat etmeyenlere ok fırlattı, kılıç salladi.

11- Düşmanla nasıl savaşılacă̆ını, yüreklerinden vuracaklarını ve zırhlanacaklarım ve böylece gözlerin nasıl da şaşıp kalacă̆ıı Me'ad² kabilesine öğrettiler.

12- Safkan atların sırtında onların nasıl sürüleceğini ve içerisinde kırmızılık bulunan terle terleyecek şekilde nasıl o atların yorulacă̆ını onlara ögrettiler.

13- Ey bizden insaflı olmamızı ve bize komşu olmayı isterken yanlış yol izleyen Benî Hacer!

14- Küçük atımla size hücum etsem yeter, aranıza dalar ve sizi yenerim.

31 Cürhüm Yemen'de bir kabiledir. Bk. İsfahânî, el-Ağgân̂, 12: 97; Ahmet Önkal, “Cürhüm (Benî Cürhüm)", Türkiye Diyanet Vakfı İslam Ansiklopedisi (Ankara: TDV Yayınları, 1993), 8: 138.

32 Me'ad b. 'Adnân, İsmâil (a.s.)'ın torunlarından olan kuzeydeki Arapların atasıdır. Bk. Mustafa Fayda, "Adnân", Türkiye Diyanet Vakfi İslam Ansiklopedisi (Ankara: TDV Yayınlar1, 1988), 1: 391-392. 
208 | A. ŞEN \& E. DEMIR / Câhiliye Dönemi Şairlerinden el-Efveh el-Evdî'de Fahr Teması

15- Küçük atım bir kor ateş gibi size saldırır, süvarisi de elindeki ateşle sizinle savaşır.

16- Evd'den bir süvari size saldırır, şüphesiz ki o, memleketini korur.

17- Mızră̆ı zehirli bir süvari, tozlar uçuştŭ̆unda mızră̆ını kanla kırmızıya boyar.

18- Korkutucu olması cahilliğinden değildir, hilm sahibi savaşta sakin durur mu?

19- Cahil, barışta sakindir, kavmine saldırı olduğunda hilm sahibi yerinde duramaz.

20- Biz Evd'iz, Evd'in şerefli bir yolu vardır, ondan dönmeyiz.

21- Nizâr ${ }^{33}$ insanlara nispet edilmeden önce Mezhic'in ${ }^{34}$ bize bıraktı̆̆ı yol.

22- Biz öyle at süreriz ki, küçük ve sütten kesilmiş atlar bize yetişemez ve geri kalırlar.

23- Her sefere çıktığımızda, içinde yeryüzünün yırtıcılarının dolaştı̆̆ı harabeler birakırız.

24- Kuşlarn peşimizde görürsün, kendilerine öldürülen cesetlerden yiyecek bulacaklarından emindirler.

25- Büyük ordumuz toz koparır, yıldızları parlatır ve kötülükleri bitirir.

26- Insanlar bize sırtlarını döner ve kaçarlar, ancak kaçış onlara fayda vermez.

27- Hükümranlığımız krala itaat etmeyen kavmin ilk hükümranlığıdır, atalarımı Evd'in en seçkinleridir.

28- Elbette sizler, küçüklük mekânında oturan kıymetsiz tabilersiniz.

29- Biz savaş ehliyiz, savaş gününde parlak ve keskin kılıçlarımızla zafer kazandik.

30- Yerinizde kalın! Biz Mezhic'iz, az sabredin, gündüz geceleyin gizlenenleri rezil eder.

Efveh yine Kuzey Araplarına karşı mücadeleleri çerçevesinde gerçekleşen savaşlardan bahsettiği bir şiirinde, kavminin ve kendisinin hamiyetperverliğine, cömertliğine ve komşularını korumak için

33 Adnânîler'in ana kollarından birini teşkil eden Arap kabilesi. Bk. Mustafa Sabri Küçükaşcı, "Nizâr b. Mead (Beni Nizâr b. Mead)", Türkiye Diyanet Vakfi İslam Ansiklopedisi (Ankara: TDV Yayınları, 2007), 33: 198, 199.

34 Kahtaniler'e mensup Yemenli bir Arap kabilesi. Bk. Câsim Avc1, "Mezhic”, Türkiye Diyanet Vakfi Islam Ansiklopedisi (Ankara: TDV Yayınları, 2004), 29: 543. 
A. ŞEN \& E. DEMIR / The Theme of Fakhr in the Works of Jahiliyyah Period Poet al-Afwah al-Awdi | 209 gösterdiği fedakârlığa değinirken, atı üzerinde savaş meydanına korkusuzca atıldığını söyler: (Serî')

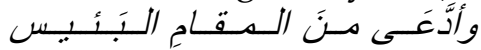

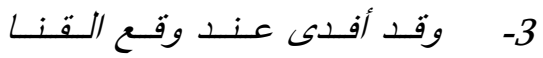

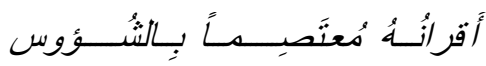

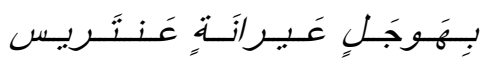

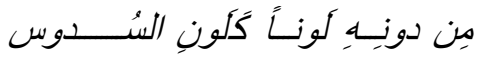

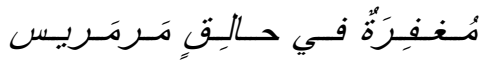

$$
\begin{aligned}
& \text { للِحَرب أَو للِجَدبِ عـامَ الثَــــوس }
\end{aligned}
$$

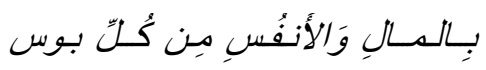

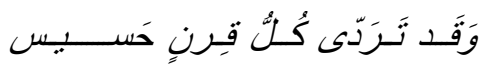

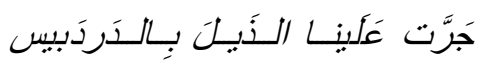

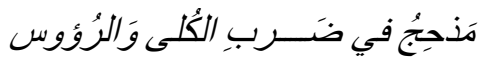

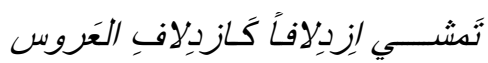

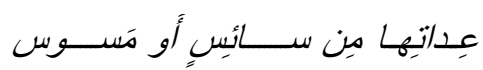

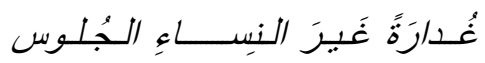

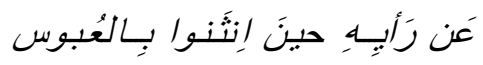

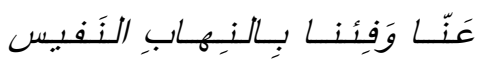

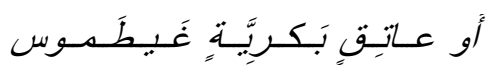

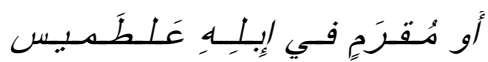

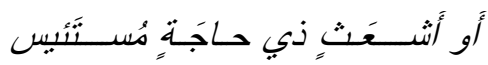

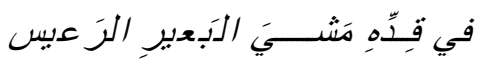

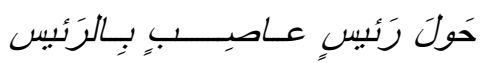

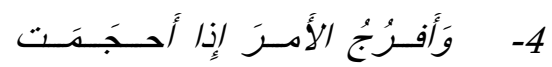

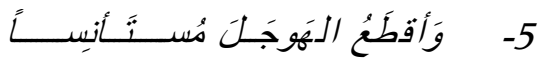

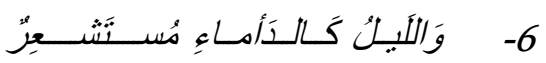

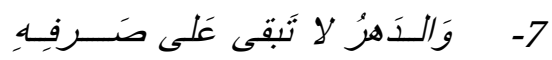

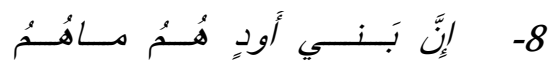

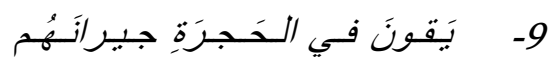

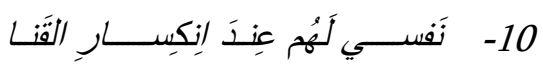

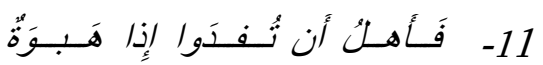

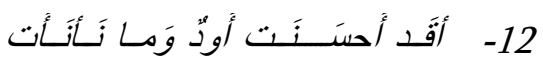

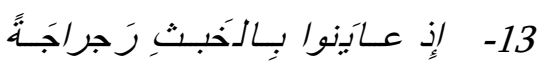

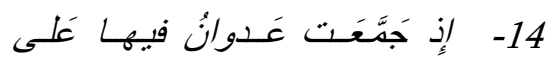

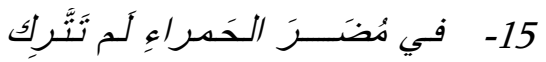

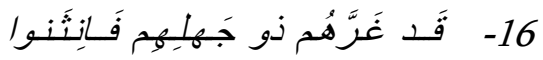

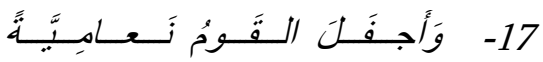

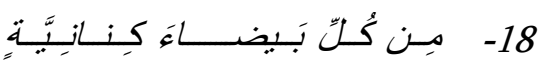

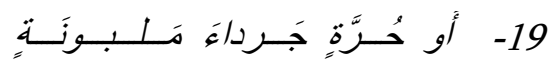

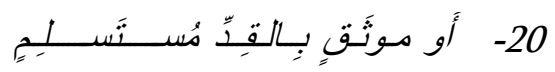

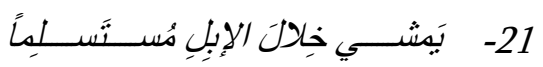

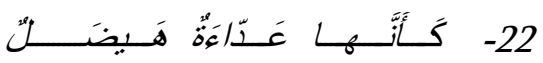


210 | A. ŞEN \& E. DEMİR / Câhiliye Dönemi Şairlerinden el-Efveh el-Evdî'de Fahr Teması
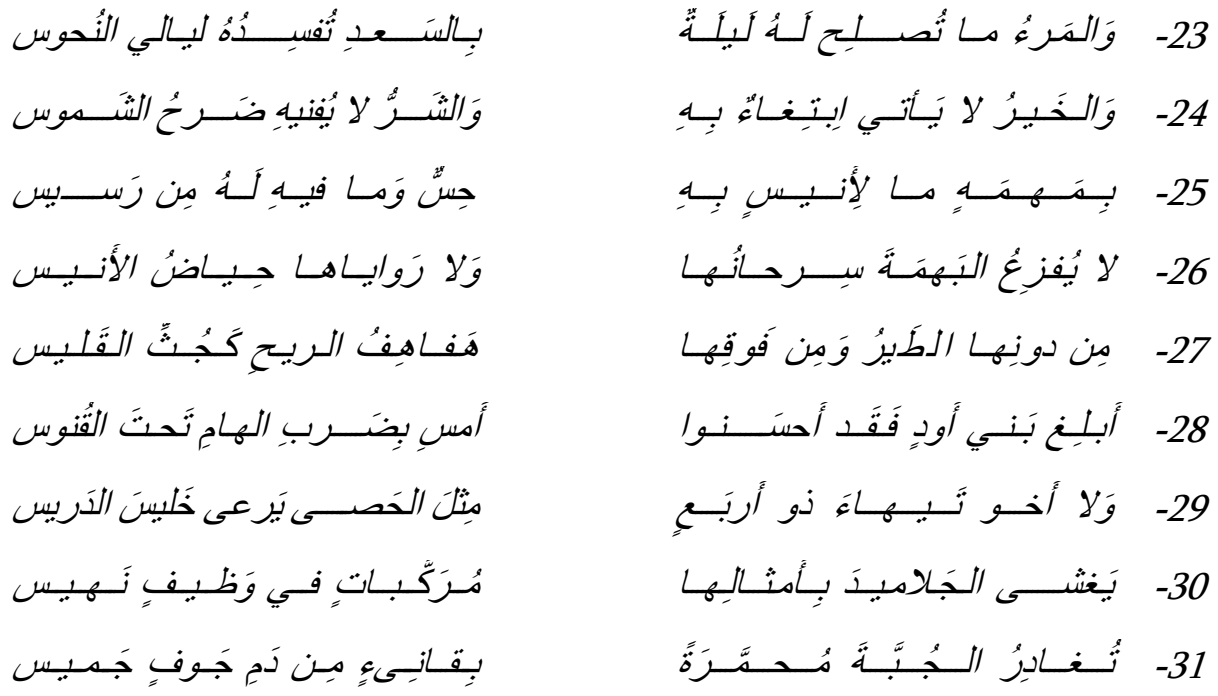

3- Mızrakların çarpıştığı savaş anında adamlar kendilerini bana feda etmiş ve beni sefil makamımdan yukarıya taşımışlardır. hallederdim.

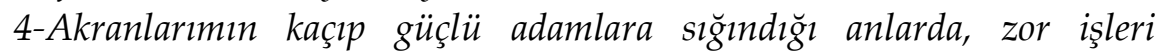

5- Güçlü, atik ve sert develerin sırtında uzak yerlere giderdim.

6- Ve önümdeki yeşil renkli çöllere bakarak, geceleyin deniz gibi karanlık çölleri aşardım.

7- Zaman, çorak yükseklerde yaşayan dă̆ keçisini bile hâline bırakmaz, yakalar.

8- Şüphesiz Benî Evd, eskiden beri, savaş, kıtlık ve zorluk anlarında cesaret ve önderlikleriyle bilinirler.

9- Sıkıntılı yıllarda komşularını mal ve canlarıyla her türlü zorluğa karşı korurlar.

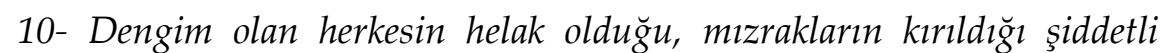
savaşlarda canım onlara feda olsun.

11- Savaşın tozları ve felâketi üstümüze geldiğinde, Ey komşularım, ailemsiniz, feda olunmaya lâyıksınız.

12- Şüphesiz Evd iyi davrand, Mezhic de savaşlarda düşmanlarm böbreklerini sökmekte ve başlarını vurmakta aciz davranmadı. 
A. ŞEN \& E. DEMIR / The Theme of Fakhr in the Works of Jahiliyyah Period Poet al-Afwah al-Awdi | 211

13,14- Meydanda savaş topluluğu gördüğ̈̈̈nde, onlara doğru yaklaşır ve meydanı kuşatırlardı 'Advân ${ }^{35}$ kabileleri efendileri ve tabileriyle düşmanlarına karşı durduklarında.

15- Mudaru'l-Hamrẩ $\hat{b}^{\prime}$ da oturan kadınların dışında kimse kalmadı (herkes geldi).

16- Cahilleri onları kandırdı, savaşın kederiyle karşılaşınca görüşlerinden vazgeçip geri çekildiler.

17- Kavim deve kuşu gibi bizden kaçtı, biz ise, mükemmel ganimetlerle döndük.

18- Kinânelerin küçük çocukları Bekirlerin küçük kızları en güzel ganimetlerimizdendi.

19- Veya sütle beslenmiş tüysüz güçlü atlar veya değerli develer.

20- Yahut değerli olduklarından dolayı bağlanmış veya binilmekten ümit kesilmiş atlar.

21- Kaderine boyun eğmiş ve başın sallayarak yürüyen teslim olmuş develer.

22- Bu develer, reislerinin etrafinda toplanmış silahl bir topluluk gibiydiler.

23- Kişiyi bir gece mutlu kılarsa, bela geceleri de onu ifsat eder.

24, 25- Bizi kuşatan iyilik, bize sevgisinden gelmez, kötülü̆ğ̈ ise, inatçı hayvanlar yok edemez ünsiyet edilecek kimsenin ve sahih haberin olmadı̆̆ı uzak çöllerde.

26- Çöldeki hayvanları korkutacak kurt yoktur, su havuzları sulayacak hayvan bulamaz.

27- Ötesinde kuşlar uçuşur, üstünde rüzgâr sert eser ve bal arısı gibi vizıldar.

28- Ben̂े Evd'e söyleyin, dün savaşta miğfer altındaki başların üstüne vurmakla iyi yaptılar.

29- Çakıl taşları gibi çok sayıda otlanan hayvanları ele geçirdiler.

35 Mudarlardan bir kabilenin adı. Kuzey Araplarından ve şâirin kavminin düşmanlarıdırlar. Bk. Ahmet Önkal, "Kays Aylân (Benî Kays Aylân)", Türkiye Diyanet Vakfı İslam Ansiklopedisi (Ankara: TDV Yayınları, 2002), 25: 91, 92.

36 Mudar kabilesinin diğer adıdır. Bk. Mustafa Sabri Küçükaşcı, "Mudar (Benî Mudar)”, Türkiye Diyanet Vakfı İslam Ansiklopedisi (Ankara: TDV Yayınları, 2005), 30: 358, 359. 
212 | A. ŞEN \& E. DEMIR / Câhiliye Dönemi Şairlerinden el-Efveh el-Evdî'de Fahr Teması

30- Ince ayaklı ve zayıf deve ve atlarla kayalikları sardilar.

31- Gözler, kurumuş olan karından gelen kanlarla kızarmış haldedir.

Efveh savaş meydanında babasının cesaretine değindiği şiirinde kavminin düşmana saldıracağı vaktin sabahın erken vakti olduğuna ve savaş araçları olan at, kılıç ve mızrağa değinir: (Tavîl)

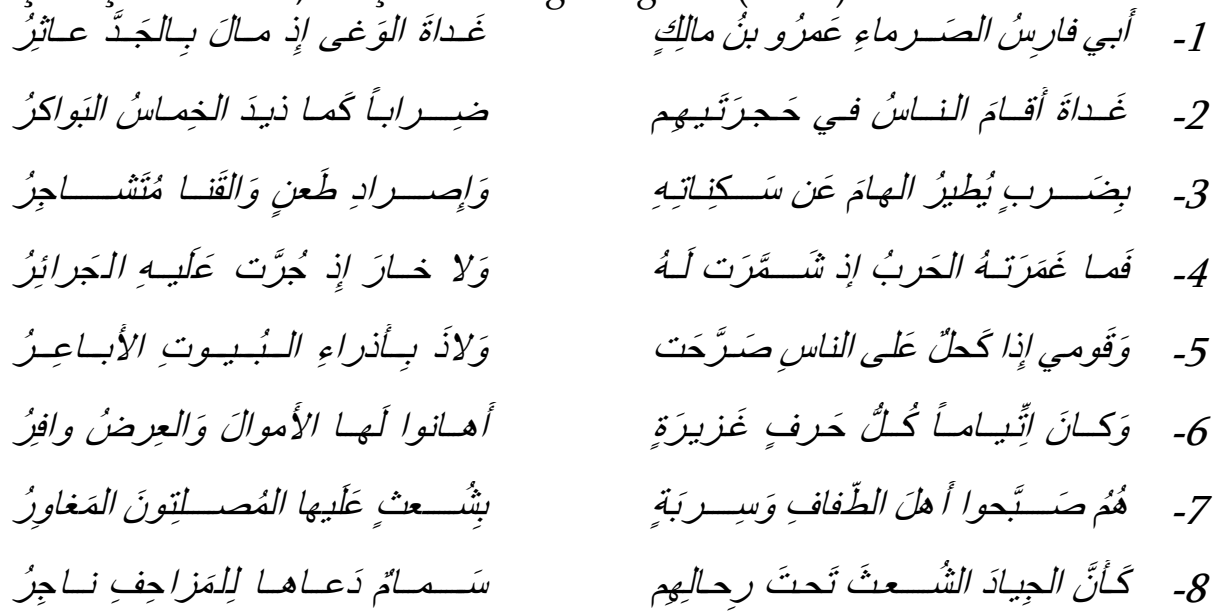

1- Babam süvari 'Amr b. Mâlik, tökezleyenlerin olduğu vakitte savaşa erkenden atılırdı.

2- Insanların diyarlarında ikamet ettiği sabah vakti vururduk, develerin sulanmak için tutulması gibi.

3- Başları uçuran kılıçların, şiddetle çarpışan ve bedenlere saplanan mızrakların vuruşuyla...

4- Onu savaş korkutmaz çünkü ona hazırdır, suçlar ona yıkılsa da kuvvetten düşmez.

5- Kavmim, kıtlık insanları kuşattı̆̆ı ve hayvanların tersi evlerin etrafına yapıştığı zaman,

6- Değerli tüm develer kesildiği zaman, malların harcadılar, onurlarını korudular.

7- Toz toprak içindeki iyi atlar üstündeki bu cesur savaşçılar, Tafâf ${ }^{37}$ ve Sirbe'ye $e^{38}$ sabahleyin girdiler.

37 Yer ismidir. Bk. Hamevî, “Tafâf”, 4: 35.

38 Yer ismidir. Bk. Ahmed Rızâ, Mu'cemu Metni'l-Luga (Beyrut: Dâru Mektebeti'l-Hayât, 1958), 3: 134. 
A. ŞEN \& E. DEMIR / The Theme of Fakhr in the Works of Jahiliyyah Period Poet al-Afwah al-Awdi | 213

8- Semerleri içindeki toz topră̆a bulanmış has atlar, şiddetli sıcaklı̆̆ın suya sürüklediği susuz kuşlar gibidirler.

Şair, insanlara iyilik etmek için etrafa dağıldıklarını ifade ederken kavmini çekirgelere benzetmiştir: (Kâmil)
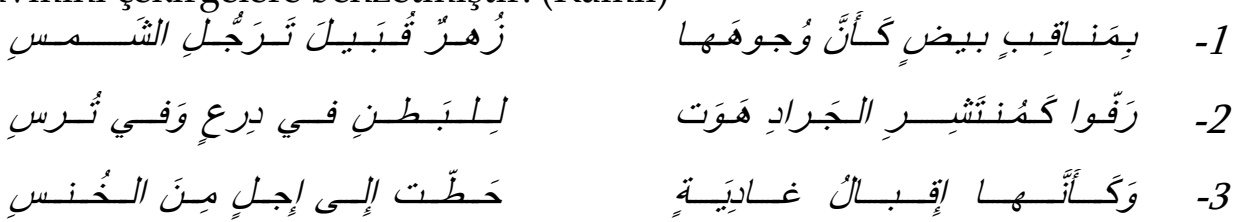

1- Kavmim güzel eylemlere sahiptir, yüzleri, güneşe yüzünü dönen çiçekler gibi parlaktır.

2- Hizmet için dağılırlar, yayılmış çekirgeler gibi, kalkan ve zırh içinde koşuşup dururlar.

3- Süratli sığırların basık burunlu ineklere saldırmaları gibi, hızlıdılar.

Şâir, herkesin kendilerine katılacak yeterlilikte olamayacağını zira savaşta kendilerinin çok cesur olduklarını belirterek övünür. Ayrıca şiirin 4. beytinde Efveh, kabilesinin misafire ikram etmedeki cömertliğini belirtir: (Remel)
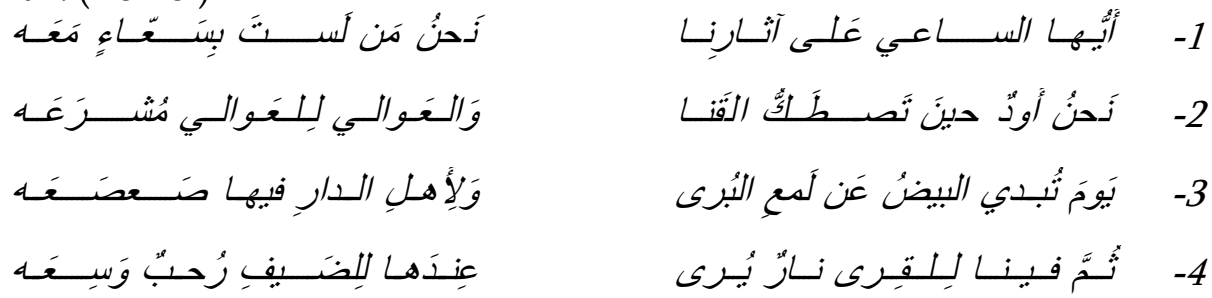

1,2- Ey izimizde yürümeye çalışan, bizimle yürüyecek biri değilsin, biz Evd'iz, uzun mızrakların birbirine girdiğ $i$ savaş anında,

3- Kadınların bilezik ve halhalların gösterdiği ve ızdırap duyduğu gün, bütün cesaretimizle savaşırız.

4- Sonra bizde misafire ikram hazırlamak için ateş ve hoş geldin temennisi vardir.

Şâir, geçmiş atalarının savaş tecrübelerinin önemine değinip onları anmış ve cesaret, cömertlik ve yardımseverlik gibi huylarıyla onları övmüştür: (Kâmil) 
214 | A. ŞEN \& E. DEMIR / Câhiliye Dönemi Şairlerinden el-Efveh el-Evdî'de Fahr Teması

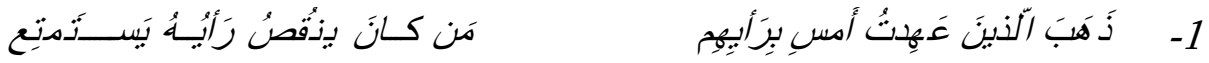

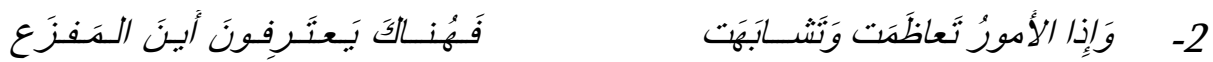

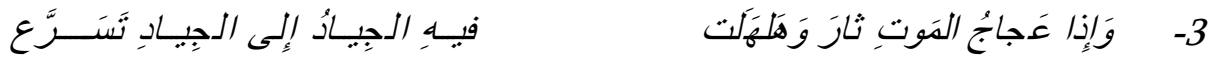

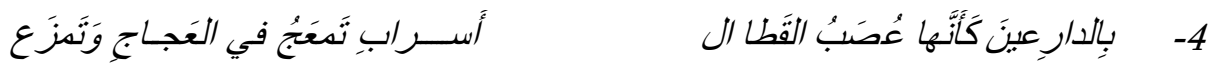

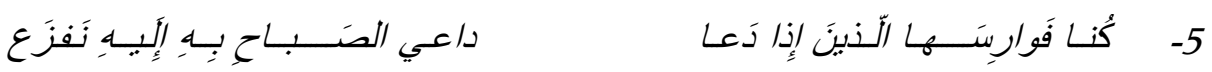

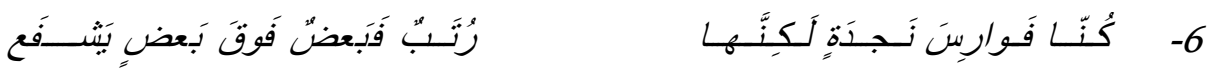

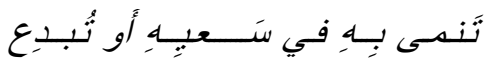

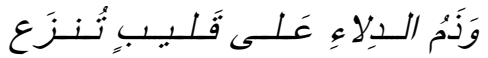

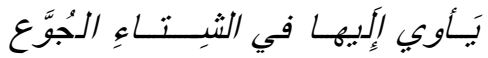

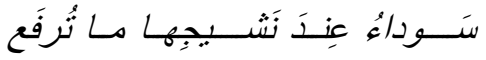

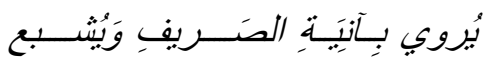

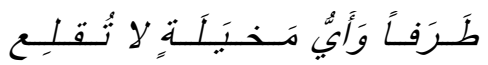

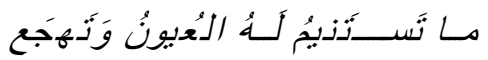

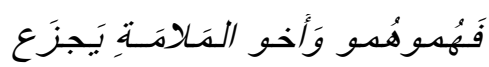

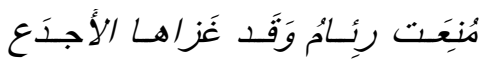

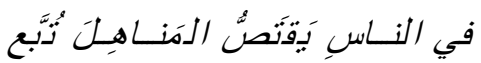

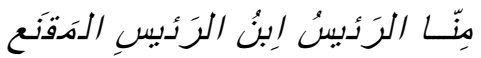

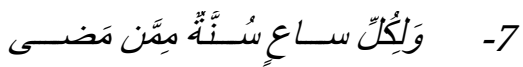

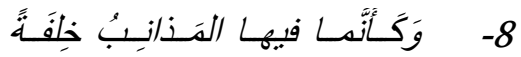

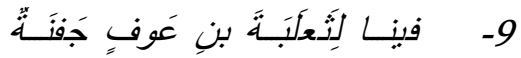

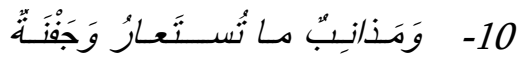

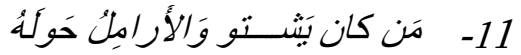

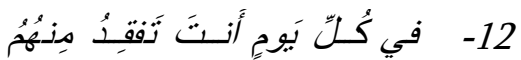

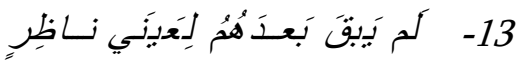

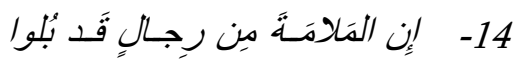

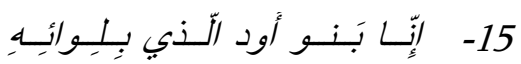

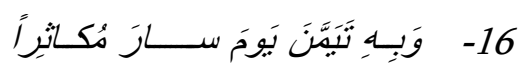

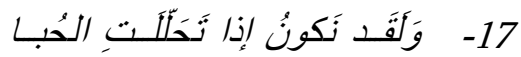

1- Dün sözlerine tutunduklarım gitti, düşüncesi zayıf olan görüş sahiplerinden istifade eder.

2- İsler büyüyüp, birbirine benzeyince, orada siğınılacak yer nerede diye itiraf ederler.

3- Savaş olunca, ölüm tozu yükselince ve atlar birbirine hızlıca yaklaşınca,

4-Tozun içine dalıp, hızlıca saldıran kuş sürüsü gibi olan, zırha bürünmüş kahramanlarımızla, 
A. ŞEN \& E. DEMIR / The Theme of Fakhr in the Works of Jahiliyyah Period Poet al-Afwah al-Awdi | 215

5-Biz, sabah vakti çă̆ıranların davetine icabet etmekte tereddüt etmeyen savaş süvarileriyiz.

6-Yardım süvarileriyiz. Ancak bu yardımın dereceleri var, bazıları bazılarından önce gelir.

7-Herkesin geçmişlerden alıp, izlediği bir metodu vardır, bu metotla ya çabasını artırır ya da hüsrana ŭgrar.

8-Sanki orada su taşkınları, peş peşe kulpundan tutulan ve kuyu suyundan doldurulan kovalar var.

9- Bizde Sa'lebe b. 'Avf'ın büyük çană̆ı var, kışın aç kalanlar ona sı̆̆ııır.

10- Kabahatler ödünç alınmaz. Kaynayan siyah çanaklar kaldırılmaz.

11- Kışa giren ve etrafinda dul kadınlar bulunan, saf gümüş tabaklarda yedirilir ve doyurulur.

12- Her gün onlardan birini kaybedersin, hangi bulut yağmur yă̆dırmaktan vazgeçer ki?

13- Onlardan sonra gözlerim manzaraya bakmaz, gözler uykuya dalmaz ve talep etmez.

14- Ancak kınama belaya uğrayan adamlardan gelir, kınayanların korkmasi gerek.

15- Şüphesiz biz, sancă̆gyla Rîâm'a girişi engellenen ve Ecda'40 ile savaşan Evd'in çocuklarıyız.

16- Kral, onunla Ri'âm'ı kutsadı, bize yönelip, sayılamayacak kadar çok asker topladiğı zaman, Ecda' peş peşe pınarlar akıtmıştı.

17- Biz, ayă̆a kalktığımızda, ancak atalarından beri reisimiz olan bizi ikna edebilir.

Efveh, kavminin atlarını önce Gaydân'a ardından da önce el-Garkî ve el-'Arcâ'ya sürdügüunü sonra onların Tafâf'a ilerlediğinden ve tüm bu bölgelerdeki halka saldırı gerçekleştirdiğinden övünerek bahseder:(Vâfir)
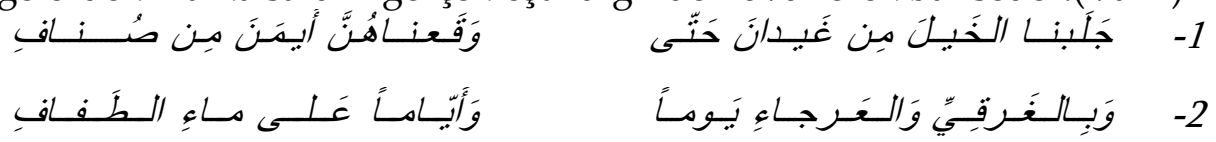

39 Yemen'de ziyaret edilen bir mabeddir. Bir rivayete göre de, bir şehirdir. Bk. İbn Manzûr, "Reeme", 12: 224.

40 Himyer krallarındandır. Bk. Ebû 'Ubeyd, Mu'cemu Mestu'cime min Esmâi'l-Bilâd ve'lMevâdi', 2: 620 . 
216 | A. ŞEN \& E. DEMIR / Câhiliye Dönemi Şairlerinden el-Efveh el-Evdî'de Fahr Teması geçirdik.

1- Gaydân'dan ${ }^{41}$ atlar getirdik, ta ki Sunâf Dă̆̆ı'nın să̆ından onları

2- Bir gün Garki ${ }^{42}$ ve 'Arcâ'da,43 başka günlerde de Tafaf'ta ${ }^{44}$ saldırdik.

Efveh, Benî 'Âmir kabilesine karşı övünürken söylediği şiirinde, kavimlerle savaştıklarını ve onların kadınlarını esir aldıklarını fakat hiçbir kavmin kendi kadınlarını esir alamadığını ifade eder. Şâir, kavminin düşmanı olup savaştı̆̆ı Benî 'Âmir'e, intikam hususunda kararlı olduklarını diyet ödemeyi de kan dökmeye tercih ettikleri mesajını iletir: (Tavîl)

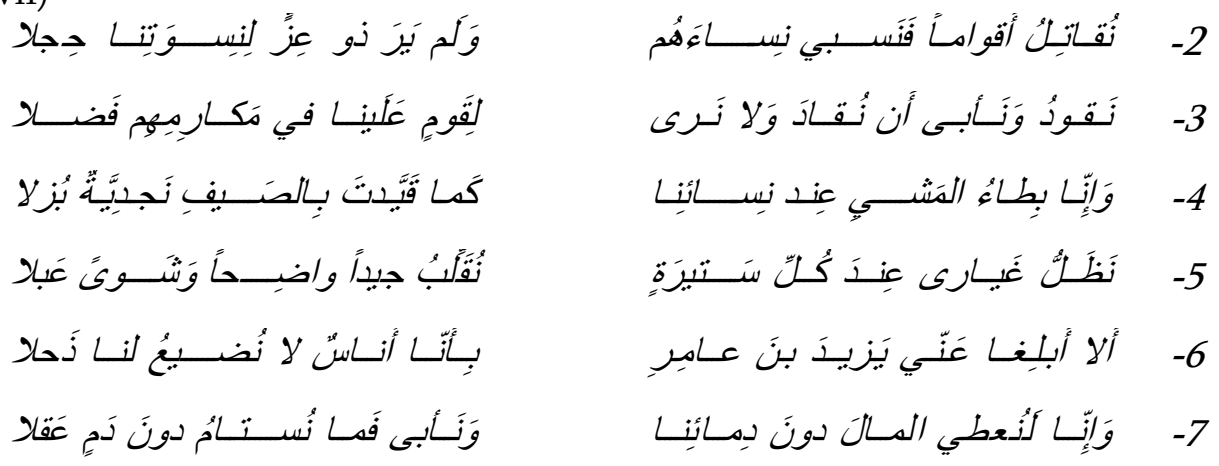

2- Kavimlerle savaşırız ve kadınların esir alırız, güç sahibi hiç kimse de kadınlarımızın halhallarını göremez.

3- Öncülük ederiz ama boyun eğmeyiz, iyiliklerinde hiçbir kavmi kendimizden üstün görmeyiz.

4- Şüphesiz biz, yazın yağmurun hareket etmesini engellediğ $i$ güçlü antilop gibi kadınlarımızın yanına yavaş yürürüz.

5- Biz örtünmüş kadınlara karşı çok kıskancız, boyunları açık, elleri doludur.

6- Dikkat edin, benden Yezîd b. 'Âmir'e iletin; biz intikamımızı yerde birakmayan insanlariz.

41 Yemen'de bir yerin adıdır. Bk. Hamevî, “Abedân”, 4: 77.

42 Yer ismidir. Bk. Hamevî, “Garkî”, 4: 194.

43 Yer ismidir. Bk. Ebû 'Ubeyd, “'Arcâ'”, 3: 931.

44 Yer ismidir. Bk. 34. dipnot. 
A. ŞEN \& E. DEMIR / The Theme of Fakhr in the Works of Jahiliyyah Period Poet al-Afwah al-Awdi | 217

7- Şüphesiz biz, canımızın yerine mal veririz, hakkımız olan diyet konusunda pazarlık yapmayız.

Şâir, Mereyb ve Me'rib yurdu kavminin nasıl savaşçı olduğunu bildiğini, dileyenin onlara sormasını önerirken, orada yaptıkları savaştan elde ettikleri genç kızları ve kadınları da zikrederek kavmini över: (Tavîl)

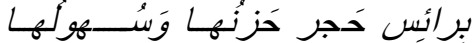

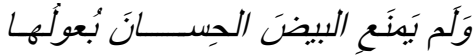

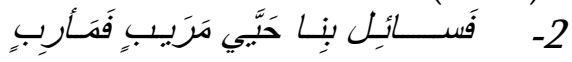

3-

2- Bizi Raisu Hacr'deki ${ }^{45}$ Mereyb ${ }^{46}$ ve $M e^{\prime}$ rib $^{47}$ diyarlarna sor; kolay ve zor yer birakmadan onlara saldırdik.

3- Ceylan gibi kızlar ve kadınlarla döndük, kocaları onları kurtarmak için bir şey yapamad.

Şâir, kavminin düşmana saldırı şeklini öğrenmek isteyen kimseden bunu kavmine ve düşmana sormasını ister. Efveh, düşman kavmin liderlerini kendilerine yiyecek vermelerini ümit eder bir halde ve eşlerini gözyaşları içinde bıraktıklarını söyleyerek kavminin askerî gücüyle iftihar eder: (Vâfir)
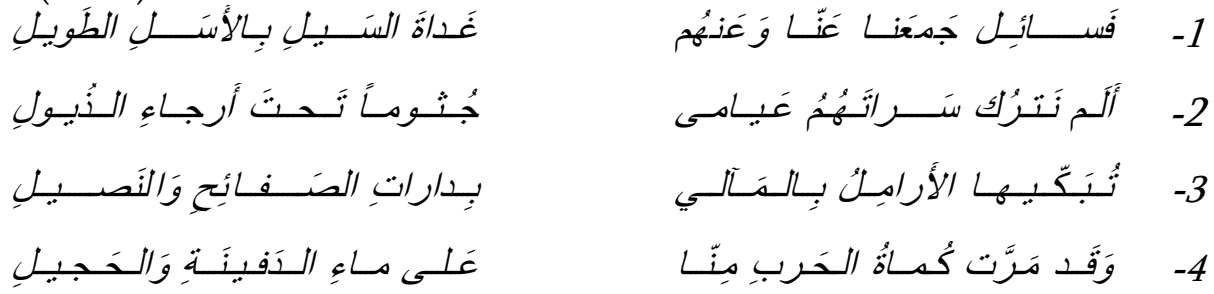

1- Bize ve düşmanlarımıza bir sor bakalım, sel sabahında uzun mızraklarımızla onlara hücum ettiğimiz zamanı.

2,3- (O zaman) Liderlerini elbiseleri içinde uyurken süt içme temennisinde bırakmadık mı? Dul kadınlar, Dârâtu's-Safâ'ih ${ }^{48}$ ve Nasîl'deki ${ }^{49}$ ellerindeki yas ve gözyaşı mendilleriyle yas tutarlarken.

45 Yer ismidir. Bk. Ebû 'Ubeyd, "Râis", 2: 624.

46 Yemen'de bir kabiledir. Bk. Ebû 'Ubeyd, "Marib”, 4: 1170.

47 Ezd kabilesinin yurdudur. Bk. Ebu'l-Kâsım Mahmûd b. 'Amr ez-Zemahşerî, el-Cibâlu ve'l-Emkinetu ve'l-Miyâhu (Kahire: Dâru'l-Fadîle, 1999), 36.

48 Yer ismidir. Bk. Hamevî, “Dâratu's-Safâih”, 2: 428.

49 Bir kuyunun ismidir. Bk. Hamevî, "Nasîl”, 5: 289. 
218 | A. ŞEN \& E. DEMİR / Câhiliye Dönemi Şairlerinden el-Efveh el-Evdî'de Fahr Teması

4- Silah kuşanmış süvarilerimiz Defìne ve Hacîl ${ }^{50}$ suyuna bizi ulaştırdılar.

Efveh yine bir lâmiyesinde, kavminin Dârâtu Cuhd, Sârâtü Cunbul, Kesîb, 'Azhel ve Efkel gibi yerlerde düşmanı bozguna uğrattıklarını belirterek kavmiyle gurur duyar ve onları över: (Tavîl)

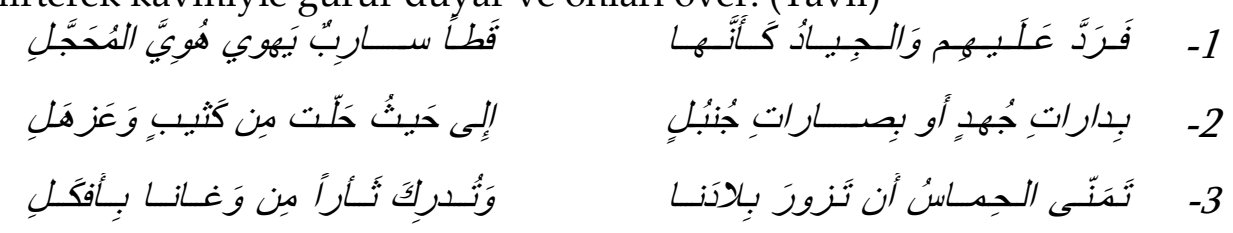

1- Onlara saldırdı, atlar, yere doğru inen kuşun uçması gibi, onlara doğru yöneldi.

2- Dârâtu Cuhd51 veya Sârâtu Cunbul'dan ${ }^{52}$ bir kum tepesine ve 'Azhel' $e^{53}$ varıncaya kadar birçok yerde onlara saldırdık.

3- Efkel'de ${ }^{54}$ onları yendiğimizden dolayı cesur savaşçılar yurdumuza vartp, intikam almak istediler.

\section{Sonuç}

Mezhic kabilesine mensup Salâ'e b. 'Amr el-Efveh, Arapların meşhur süvarilerinden biri olup, hayatı boyunca çok sayıda savaşa katılmıştır. Cahiliye döneminin bu ünlü savaş̧̧ısı aynı kavminin lideri olup şiirlerinde kavmiyle övünmüştür. Onun şairliği hakkında âlimlerden çok sayıda görüş nakledilmiştir. Şiirlerinde kullandığı kelime ile tasvirlerden dolayı Efveh'in şiirleri ve şairliği diğer yönlerinin önüne geçirilmiştir.

Efveh, fahr şiirlerini genel olarak özellikle Kuzey Arapları ile yaptıkları savaşlarda kavminin kazandığı başarılar ve savaş meydanlarında sergilediği performans üzerine bina etmiştir. Bu tür şiirlerinde Efveh, kabilesine mensup savaşçlların ata binme, kılıç kullanma yeteneği, cesaretlerine değinmiştir. Ayrıca yalnız savaş meydanında değil savaş dışında da yine kendisinin ve kavminin sahip olduğu hakka riayet etme, her durumda hakkı savunma,

50 İki su kaynağı ismidir. Bk. Hamevî, “Hacîl”, 2: 226.

51 Yer ismidir. Bk. Hamevî, "Dâretu Cuhd", 2: 426.

52 Yer ismidir. Bk. Hamevî, "Cunbul”, 2: 168.

53 Yer ismidir. Bk. Ebû 'Ubeyd, "Azhel”, 3: 941.

54 Yer ismidir. Bk. İbn Manzûr, "Fekele”, 11: 530. 
A. ŞEN \& E. DEMIR / The Theme of Fakhr in the Works of Jahiliyyah Period Poet al-Afwah al-Awdi । 219

hamiyetperverlik, cömertlik ve fedakârlık gibi bazı ahlâkî nitelikleri, zikreder. Bu gibi özelliklerle övünme cahiliye devri fahr şiirlerinde genel olarak görülen bir durumdur.

\section{Kaynakça}

Ahmed Rizâ. Mu'cemu Metni'l-Luga. 5 Cilt. Beyrut: Dâru Mektebeti'1Hayât, 1958.

'Askerî, Ebû Hilâl. Dîvânu'l-Ma'ânî. 2 Cilt. Beyrut: Dâru'l-Cîl, ts.

'Askerî, Ebû Hilâl. es-Sınâ'ateyn. Nşr. Muhammed Ebu'l-Fadl İbrâhîm - Ali Muhammed el-Becâvî. Beyrut: el-Mektebetu'l-`Unsuriyye 1419/1999.

Ahfeş, 'Ali b. Süleyman. el-İhtiyâreyn. Nşr. Fahreddin Kabâve. Beyrut: y.y., 1420/1999.

Ahmed Matlûb. Mu'cemu Mustalahâti'n-Nahvi'l-'Arabiyyi'l-Kadîm. Beyrut: Mektebetu Lubnân, 2001.

Avcı, Câsim. "Mezhic". Türkiye Diyanet Vakfi İslâm Ansiklopedisi. 29: 543. Ankara: TDV Yayınları, 2004.

Cebbûr 'Abdunnûr. el-Mu'cemu'l-Edebî. Beyrut: Dâru'l-'İlm li'l-Melâyîn, 1979.

Cevherî, Ebû Nasr İsmâ'îl b. Hammâd. "Fahara". Sihâh. Nşr. Ahmed 'Abdulgafûr 'Attâr. 2: 779. 6 Cilt. Beyrut: Dâru'l-'İlm li'l-Melâyîn, 1407/1987.

Demirayak, Kenan. Arap Edebiyatı Tarihi-1. Erzurum: Fenomen Yayıncilık, 2012.

Durmuş, İsmail. "Fahr". Türkiye Diyanet Vakfi İslâm Ansiklopedisi. 12: 79. Ankara: TDV Yayınları, 1995.

Durmuş, İsmail. "Hamase". Türkiye Diyanet Vakfi Íslam Ansiklopedisi. 15: 437. İstanbul: TDV Yayınları, 1997.

Ebû 'Ubeyd 'Abdullah b. 'Abdul'azîz el-Endelûsî. Mu'cemu Mestu'cime min Esmâi'l-Bilâd ve'l-Mevâdi'. 4 Cilt. Beyrut: 'Alemu'l-Kutub, 1983.

Efveh, Salâ'e b. 'Amr el-Evdî. Dîvân. Nşr. Muhammed Altuncî. Beyrut: Dâru Sâdır, 1998.

Ezherî, Muhammed b. Ahmed. “Fahara”. Tehzîbu'l-Luga. Nşr. Muhammed 'Avad. 7: 154. 8 Cilt. Beyrut: y.y., 2001.

Fâhûrî, Hannâ. el-Fahr ve'l-Hamâse. Kahire: Dâru'l-Ma'ârif, 1992. 
220 | A. ŞEN \& E. DEMIR / Câhiliye Dönemi Şairlerinden el-Efveh el-Evdî'de Fahr Teması

Farès, Bichr. "Müfâhare”. İslam Ansiklopedisi. 8: 790-791. İstanbul: y.y., 1940-1988.

Fayda, Mustafa. "Adnân". Türkiye Diyanet Vakfı İslâm Ansiklopedisi. 1: 391392. Ankara: TDV Yayınları, 1988.

Hamevî, Yâkût b. 'Abdillâh. "Hacîb". Mu'cemu'l-Buldân. 2: 226. 7 Cilt. Beyrut: Dâru Sâdır, 1995.

Hemedânî Hasen b. Ahmed. Sıfatu Cezîreti'l-'Arab. Nşr. Muhammed b. 'Ali el-Ekva' el-Hûlî. San'â': Mektebetu'l-İrşâd, 1990.

İbn Dureyd, Ebû Bekr Muhammed b. el-Hasen. "Fahara". Cemheretu'lLuga. Nşr. Remzî Munîr Ba'lbekkî. 1: 589. 3 Cilt. Beyrut: Dâru'l-’Ilm li'l-Melâyîn, 1987.

İbn Fâris, Ebû'l-Huseyn Ahmed. "Fahara”. Mu'cemu Mekâyîsi'l-Luga. Nşr. 'Abdusselâm Muhammed Hârûn. 4: 480. 4 Cilt. Kahire: y.y., 1366/1946.

İbn Hazm, Ebû Muhammed Ali b. Ahmed. Cemheretu Ensâbi'l-'Arab. Beyrut: Dâru'l-Kutubi'l-'ilmiyye, 1403/1983.

İbn Kuteybe, Ebû Muhammed Abdullāh b. Müslim ed-Dîneverî. eş-Şi'r ve'ş-Şu'arâ'. 2 Cilt. Kahire: Dâru'l-Hadîs, 1423/2003.

İbn Manzûr, Muhammed b. Mukerrem el-İfrikî el-Misrî. "Hacebe". Lisânu'l-'Arab. 1: 300. 15 Cilt. Beyrut: Dâru Sâdır, 1414/1993.

İbn Reşîk el-Kayrevânî. el-‘Umde. 2 Cilt. Nşr. Muhammed Muhyiddîn 'Abdulhamîd. Beyrut: y.y., 1401/1981.

İbn Sellâm el-Cumahî. Tabakâtu Fuhûli'ş-Şu'arâ'. 2 Cilt. Nşr. Mahmûd Muhammed Şâkir. Cidde: y.y., ts.

İbn Sîde, Ebu'l-Hasen 'Ali b. İsmâ'îl. el-Muhkem ve'l-Muhîtu'l-A'zam. 6 Cilt. Nşr. Hindâvî. Beyrut: Dâru'l-Kutubu'l-'ilmiyye, 1421/2000.

İsfahânî, Ebü'l-Ferec Ali b. Hüseyin. el-A ğânî̀. 27 Cilt. Beyrut: Dâru İhyâ'i'tTurâsi'1-'Arabî, 1415/1995.

Küçükaşc1, Mustafa Sabri. “Nizâr b. Mead (Benî Nizâr b. Mead)”. Türkiye Diyanet Vakfi İslâm Ansiklopedisi. 33: 198-199. Ankara: TDV Yayınları, 2007.

Küçükaşcı, Mustafa Sabri. “Mudar (Benî Mudar)”. Türkiye Diyanet Vakfı İslâm Ansiklopedisi. 30: 358-359. Ankara: TDV Yayınları, 2005.

Ömer Ferrûh. Târîhu'l-Edebi'l-'Arabî. 4 Cilt. Beyrut: Dâru'l-'İlm li'1Melâyîn, 1981. 
A. ŞEN \& E. DEMIR / The Theme of Fakhr in the Works of Jahiliyyah Period Poet al-Afwah al-Awdi । 221

Önkal, Ahmet. “Cürhüm (Benî Cürhüm)”. Türkiye Diyanet Vakfı İslâm Ansiklopedisi. 8: 138. Ankara: TDV Yayınları, 1993.

Önkal, Ahmet. "Kays Aylân (Benî Kays Aylân)". Türkiye Diyanet Vakfı İslâm Ansiklopedisi. 25: 91-92. Ankara: TDV Yayınları, 2002.

Şeyho, Luvîs Rızkullah b. Yûsuf el-Yesû'î Luvîs. Şu'arâ'u'n-Nasrâniyye. 3 Cilt. Beyrut: y.y., 1890.

Zemahşerî, Ebu'l-Kâsım Mahmûd b. 'Amr. el-Cibâlu ve'l-Emkinetu ve'lMiyâhu. Kahire: Dâru'l-Fadîle, 1999.

Ziriklî, Hayreddin. el-A'lâm. 8 Cilt. Beyrut: Dâru'l-'İlm li'l-Melâyîn, 2002. 